\title{
The Nitric Oxide/cGMP Pathway Couples Muscarinic Receptors to the Activation of $\mathrm{Ca}^{2+}$ Influx
}

\author{
Chris Mathes and Stuart H. Thompson \\ Department of Biological Sciences and the Hopkins Marine Station, Stanford University, Pacific Grove, California 93950
}

Inward currents activated by 8-bromo-cGMP and by muscarinic agonist were compared in N1E-115 mouse neuroblastoma cells using perforated-patch voltage clamp and Fura- 2 imaging. The cGMP analog activates a voltage-independent inward current that is carried at least in part by $\mathrm{Ca}^{2+}$ because it persists in $\mathrm{Na}^{+}$-free saline when $\mathrm{Ca}^{2+}$ is present and is blocked by external $\mathrm{Mn}^{2+}$ and $\mathrm{Ba}^{2+}$. The current is similar to the inward current that develops during stimulation of $\mathrm{M} 1$ muscarinic receptors, and the currents activated by agonist and by 8-bromocGMP are not additive, indicating that the same pathway is involved. Inhibition of cGMP production with $\mathrm{N}_{\mathrm{G}}$-monomethylL-arginine (L-NMMA), a competitive inhibitor of nitric oxide (NO)-synthase, prevents activation of $\mathrm{Ca}^{2+}$ current by agonist without affecting the content of intracellular $\mathrm{Ca}^{2+}$ stores or the ability of agonist to mobilize $\mathrm{Ca}^{2+}$. The inhibition is overcome by 8-bromo-cGMP. LY83583, a competitive inhibitor of gua- nylyl cyclase, reversibly blocks activation of $\mathrm{Ca}^{2+}$ current by agonist, again without affecting the content of $\mathrm{Ca}^{2+}$ stores or $\mathrm{Ca}^{2+}$ release. Rp-8-pCPT-cGMPS, an inhibitory analog of cGMP, also reduces the $\mathrm{Ca}^{2+}$ current and reduces $\mathrm{Ca}^{2+}$ influx during muscarinic activation. It is concluded that cGMP is the necessary and sufficient intermediate in the pathway linking muscarinic receptor occupancy to the activation of voltageindependent $\mathrm{Ca}^{2+}$ current. The pathway involves positive feedback. Calcium entering via voltage-independent channels preferentially stimulates NO-synthase, which leads to enhanced cGMP production and greater $\mathrm{Ca}^{2+}$ influx. Positive feedback may explain the rapid increase in CGMP that occurs during muscarinic receptor activation.

Key words: cGMP; nitric oxide; calcium current; muscarinic receptors; signal transduction; $\mathrm{Ca}^{2+}$ imaging
Muscarinic acetylcholine receptors stimulate multiple secondmessenger pathways that can powerfully modify the physiological activity of neurons. We studied interactions between two of these pathways in N1E-115 mouse neuroblastoma cells. Stimulation of M1 receptors in this cell line causes rapid accumulation of cGMP. This requires $\mathrm{Ca}^{2+} /$ calmodulin-dependent activation of nitric oxide (NO)-synthase to produce the second-messenger NO, which in turn activates soluble guanylyl cyclase to produce cGMP (McKinney et al., 1990; $\mathrm{Hu}$ and El-Fakahany, 1993; Thompson et al., 1995). M1 receptors also activate phospholipase $C-\beta$ via a $\mathrm{G}$-protein, and this results in the production of inositol 1,4,5trisphosphate $\left(\mathrm{IP}_{3}\right)$ and the subsequent release of $\mathrm{Ca}^{2+}$ into the cytosol from $\mathrm{IP}_{3}$-sensitive intracellular $\mathrm{Ca}^{2+}$ stores. Intracellular $\mathrm{Ca}^{2+}$ release is one of two sources of $\mathrm{Ca}^{2+}$ required to stimulate cGMP production fully. The other source involves $\mathrm{Ca}^{2+}$ influx at the membrane by a pathway that is activated subsequent to $\mathrm{Ca}^{2+}$ release (Mathes and Thompson, 1994; Thompson et al., 1995). The $\mathrm{Ca}^{2+}$ influx pathway represents an important source of $\mathrm{Ca}^{2+}$ for refilling intracellular stores once the agonist action is terminated (Mathes and Thompson, 1995), but little is known about its regulation or modulation during muscarinic signal transduction. The work of Pandol and Schoeffield-Payne (1990), Bahnson et al. (1993), and Xu et al. (1994) suggested that cGMP may be respon-

\footnotetext{
Received Sept. 18, 1995; revised Dec. 8, 1995; accepted Dec. 15, 1995.

This work was supported by National Institutes of Health Grant NS14519 (S.H.1.), a predoctoral fellowship from the American Foundation for Aging Research (C.M.), and National Institutes of Health Grant MH10425 (C.M.). We thank C. E. Thompson for her timely arrival, Drs. A. A. Alousi, J. S. Coggan, I. Kovacs, and S. S.-H. Wang for critical comment and discussion, and we thank R. Kramer and G. R. Tibbs for sharing their unpublished data.

Correspondence should be addressed to Stuart Thompson at the above address. Copyright $(1996$ Society for Neuroscience $0270-6474 / 96 / 161702-08 \$ 05.00 / 0$
}

sible for linking $\mathrm{Ca}^{2+}$ release from internal stores to the activation of voltage-independent $\mathrm{Ca}^{2+}$ current in pancreatic acinar cells. Because muscarinic activation of N1E-115 cells dramatically elevates the intracellular cGMP concentration, we considered the possibility that cGMP might activate $\mathrm{Ca}^{2+}$ current in this excitable cell line as well. This was explored using nystatin perforated-patch voltage clamp and Fura-2 imaging.

We found that 8-bromo-cGMP, a membrane permeable analog of cGMP, activates a voltage-independent $\mathrm{Ca}^{2+}$ current with propertics similar to the current activated by muscarinic agonists. Inhibitors of cGMP formation or the binding of cGMP to its effectors prevents activation of the current by agonist without affecting intracellular $\mathrm{Ca}^{2+}$ release or the content of calcium stores. We conclude that cGMP is the factor necessary for coupling muscarinic receptor occupancy to the activation of $\mathrm{Ca}^{2+}$ current. It is apparent that the $\mathrm{IP}_{3}$-signaling pathway and the cGMP pathway interact at the level of intracellular $\mathrm{Ca}^{2+}$ concentration. This interaction represents a positive-feedback loop linking increases in intracellular calcium $\left([\mathrm{Ca}]_{i}\right)$ to increased production of cGMP and increased $\mathrm{Ca}^{2+}$ influx. Positive feedback helps to explain the rapid increase in cGMP production (and by inference, NO production) that occurs during muscarinic receptor activation.

\section{MATERIALS AND METHODS}

Cell culture. The N1E-115 neuroblastoma cell line, derived from mouse sympathetic ganglion neurons (Amano et al., 1972), was obtained from the University of California San Francisco Cell Culture Facility and used in passages 3-8. Cells were grown in DMEM with $10 \%$ fetal bovine serum (HyClone, Logan, UT) at $37^{\circ} \mathrm{C}$ in a $10 \% \mathrm{CO}_{2}$ atmosphere, plated on glass coverslips, and grown to $\sim 80 \%$ confluence before differentiation with dimethyl sulfoxide (DMSO) for 5-21 d (Kimhi et al., 1976). Plated cells were fed every $2-3 \mathrm{~d}$ and used $1-2 \mathrm{~d}$ after feeding. 
Solutions and chemicals. Experiments were carried out at a temperature of $30^{\circ} \mathrm{C}$. The external saline solution contained (in $\mathrm{mM}$ ): $146 \mathrm{NaCl}, 5.4 \mathrm{KCl}, 1.8$ $\mathrm{CaCl}_{2}, 0.8 \mathrm{MgSO}_{4}, 0.4 \mathrm{KH}_{2} \mathrm{PO}_{4}, 0.3 \mathrm{Na}_{2} \mathrm{HPO}_{4}, 5$ glucose, and $20 \mathrm{HEPES}$, plus $10 \mu \mathrm{M}$ curare and $1 \mu \mathrm{M}$ tetrodotoxin (TTX), $\mathrm{pH}$ 7.4. The $\mathrm{Na}^{+}$-free, high-Ca ${ }^{2+}$ saline contained (in mM): 90 Tris- $\mathrm{HCl}, 5.4 \mathrm{KCl}, 25 \mathrm{CaCl}_{2}, 0.8$ $\mathrm{MgSO}_{4}, 10$ tetraethylammonium (TEA) chloride, 5 glucose, and 25 HEPES, plus $10 \mu \mathrm{M}$ D-tubocurarine and $1 \mu \mathrm{M}$ TTX. The bath volume $(500 \mu \mathrm{l})$ was exchanged with a gravity perfusion system (half-time for exchange $\sim 2 \mathrm{sec}$ ). Carbachol was dissolved in saline and applied at a final concentration of $1 \mathrm{mM}\left(\mathrm{EC}_{50}\right.$ for $\mathrm{Ca}^{2+}$ release $\left.=100 \mu \mathrm{M}\right)$ (Wang and Thompson, 1994). $\mathrm{N}^{\mathrm{G}}$-monomethyl-L-arginine (L-NMMA), $\mathrm{N}^{\mathrm{G}}$-monomethyl-D-arginine (D-NMMA), and 6-anilinoquinoline-5,8-quinone (LY83583) were from Calbiochen (La Jolla, CA). Rp-8-pCPT-cGMPS was from BioLog (La Jolla, CA). All other chemicals were from Sigma (St. Louis, MO). LY83583 was dissolved in DMSO and diluted to the appropriate concentration on the day of the experiment.

Nystatin-patch clamp. The nystatin perforated-patch technique was used for whole-cell voltage clamp (Horn and Marty, 1988). The pipette solution contained (in mM): $16 \mathrm{CsCl}, 70 \mathrm{Cs}_{2} \mathrm{SO}_{4}, 5 \mathrm{MgSO}_{4}, 10 \mathrm{HEPES}$, $0.05 \%$ Pluronic F-127 (Molecular Probes, Eugene, OR), and 100 sucrose $(\sim 320 \mathrm{mOsM}), \mathrm{pH}$ 7.2. With this pipette solution, the calculated equilibrium potential for $\mathrm{Cl}^{-}$for cells bathed in normal saline was $-60 \mathrm{mV}$, assuming finite permeability of nystatin to $\mathrm{Cl}^{-}$and adequate time for equilibration. Nystatin was added to filtered pipette solution from a DMSO stock ( $2.5 \mathrm{mg}$ nystatin in $50 \mu \mathrm{l}$ DMSO) to a final concentration of $100-200 \mu \mathrm{g} / \mathrm{ml}$, and this solution was used within the hour. Patch electrodes were made from Borofilament glass (Sutter Instrument, Novato, CA). Membrane currents were recorded using a List EPC-7 amplifier and PClamp software. Series resistance ranged from 20 to $40 \mathrm{~m} \Omega$, and $-50 \%$ compensation was used, allowing the cell capacitance to be compensated adequately. A holding voltage of $-60 \mathrm{mV}$ was used, which is near the normal resting potential.

$\mathrm{Ca}^{2+}$ imaging. Cells were loaded with the $\mathrm{Ca}^{21}$ indicator Fura-2 by incubation in saline containing $5 \mu \mathrm{M}$ Fura-2/AM and $0.025 \%$ Pluronic $\mathrm{F}-127$ for 1 hr at $22^{\circ} \mathrm{C}$. After the cells were rinsed, they were transferred to a heated chamber $\left(30^{\circ} \mathrm{C}\right)$ on the stage of a Nikon Diaphot equipped with a $20 \times$ Fluor objective, Hamamatsu C2400 SIT camera and a Sony videotape recorder. Xenon arc illumination was filtered through $10 \mathrm{~nm}$ bandpass interference filters with 340 and $380 \mathrm{~nm}$ center wavelengths. Calibration of fluorescence to units of $\mathrm{Ca}^{2+}$ was performed off-line using a pipeline inage processor (Megavision, Santa Barbara, CA). Background-subtracted and frame-averaged $F_{340} / F_{380}$ ratios were calibrated using standard solutions between two coverslips, according to the equations of Grynkiewicz et al. (1985). Intracellular $\mathrm{Ca}^{2+}$ concentrations were measured in regions of interest corresponding to the interiors of individual cell bodies. Calcium kinetics were resolved by monitoring cells continuously for up to $2 \mathrm{~min}$ with $380 \mathrm{~nm}$ excitation after first obtaining $F_{340} / F_{380}$. Because dye fade during this period was insignificant, only an initial ratiometric determination was needed at the beginning of each record. The initial $F_{380}$ and $[\mathrm{Ca}]_{\mathrm{i}}$ in individual cells allowed the calculation of $F_{\min }$ and $F_{\max }$, corresponding to zero and saturating $\mathrm{Ca}^{2+}$ concentrations, using the equations:

$$
\begin{aligned}
& F_{\text {max }}=F_{380}\left(1+(\mathrm{Ca})_{\mathrm{i}} / K_{\mathrm{D}}\right) /\left(\sigma+(\mathrm{Ca})_{\mathrm{i}} / K_{\mathrm{D}}\right) \\
& F_{\text {min }}=\sigma \times F_{\text {max }},
\end{aligned}
$$

where $\sigma=F_{380, \text { min }} / F_{380, \text { max }}$ and $\sigma$ is a constant of the imaging system. $[\mathrm{Ca}]_{i}$ at later times could then be calculated from $F_{380}$ using the Henderson-Hasselbalch equation, as is done for single-wavelength dyes (Kao et al., 1989). The values of the calibration parameters $R_{\min }, R_{\max }$, and $\sigma$ were $0.056,4.85$, and 22.66 , respectively.

\section{RESULTS}

\section{Inward current activated by 8-bromo-cGMP}

Application of 8-bromo-cGMP, a membrane-permeable analog of cGMP, activates inward membrane current in N1E-115 mouse neuroblastoma cells. An example measured with permeabilizedpatch voltage clamp is shown in Figure $1 A$. When $1 \mathrm{~mm} 8$-bromocGMP was introduced in normal external saline with $1 \mu \mathrm{M}$ TTX, an inward current gradually developed that reached a current density of $0.41 \mathrm{pA} / \mathrm{pF}$ after $15 \mathrm{~min}$ at the $-60 \mathrm{mV}$ holding potential. The slow onset of the current probably results from
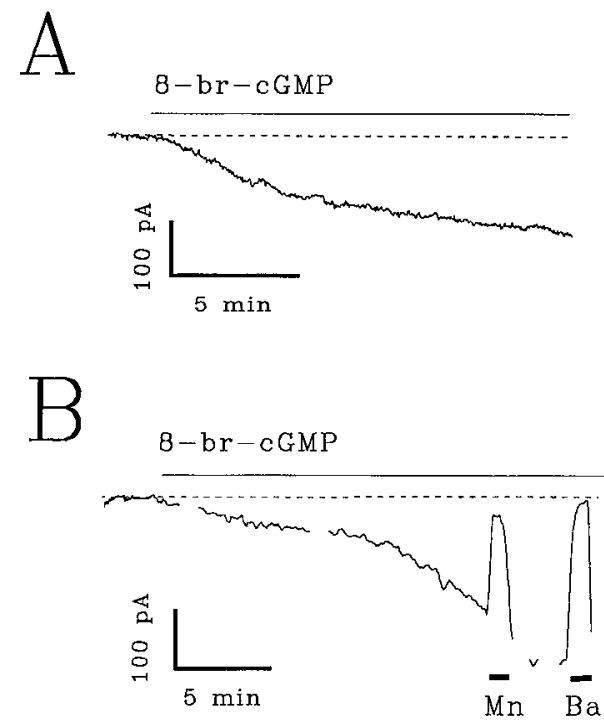

Figure 1. 8-bromo-cGMP activates a voltage-independent inward current. $A$, Membrane current measured with nystatin-patch clamp during addition of $1 \mathrm{~mm}$ 8-bromo-cGMP dissolved in normal saline (holding voltage $=-60 \mathrm{mV}$; a dashed line is drawn through the initial holding current; cell capacitance, $360 \mathrm{pF} ; R_{\mathrm{s}}=38 \mathrm{M} \Omega$ ). The agonist was applied at the time indicated by the solid bar. $B$, Inward current activated by 8-bromo-cGMP (1 mM) in a cell bathed in $\mathrm{Na}^{+}$-free, high-Ca ${ }^{2+}$ saline and voltage-clamped to $-60 \mathrm{mV}$. At the time indicated by the bar, the chamber was rinsed with $\mathrm{Na}^{+}$-free saline plus $1 \mathrm{~mm}$ 8-bromo-cGMP. After $17 \mathrm{~min}$, the chamber was rinsed again with the same saline plus $2 \mathrm{~mm}$ $\mathrm{Mn}^{2+}(M n)$ for a period of 1 min before returning to the original $\mathrm{Na}^{+}$-free saline. The procedure was repeated 3 min later using $2 \mathrm{mM} \mathrm{Ba}^{2+}(B a)$ in place of $\mathrm{Mn}^{2-1}$. Interruptions in the record correspond to times when voltage-clamp pulses were applied to measure the $I-V$ curve.

gradual entry of the cyclic nucleotide into the cell and is consistent with an intracellular site of action. The cyclic nucleotide also activates inward current in cells bathed in $\mathrm{Na}^{+}$-free, high- $\mathrm{Ca}^{2+}$ saline containing $25 \mathrm{mM} \mathrm{Ca}^{2+}$, indicating that substantial current can be carried by $\mathrm{Ca}^{2+}$ (Fig. 1B) (current density $=0.63 \mathrm{pA} / \mathrm{pF}$ after $15 \mathrm{~min}$ ). The inward current is reversibly blocked by $2 \mathrm{mM}$ external $\mathrm{Mn}^{2+}$ or $2 \mathrm{mM} \mathrm{Ba}^{2+}$, whether the cells are bathed in normal saline or in $\mathrm{Na}^{+}-$free, high-Ca ${ }^{2+}$ saline (Fig. $1 B$ ).

The difference current-voltage $(I-V)$ curve for the cyclic nucleotide-dependent current in high- $\mathrm{Ca}^{2+}$ saline is shown in Figure 2 . The points were obtained by subtracting control currents measured during pulses to voltages between -95 and $-50 \mathrm{mV}$ from currents measured during the same pulse series $15 \mathrm{~min}$ after adding $1 \mathrm{~mm}$ 8-bromo-cGMP. Difference currents calculated in this way changed instantaneously during voltage steps without evidence of time-dependent gating, indicating that the activation process is not voltage dependent within this range. The positive slope of the $I-V^{\prime}$ curve shows that the cyclic nucleotide causes a conductance increase, but it was not possible to extend the curve to voltages more positive than $-50 \mathrm{mV}$ or to measure a reversal potential, because other strongly voltage-dependent $\mathrm{Ca}^{2+}$ currents begin to activate with larger steps (Yoshii et al., 1988). Because the cGMP-dependent current is expected to be a minor component of the total $\mathrm{Ca}^{2+}$ current at depolarized voltages, it was not practical to use a pharmacological approach to isolate it. The dashed line in Figure 2 is the expected $I-V$ curve for a $\mathrm{Ca}^{2+}$ current calculated from the Goldman-Hodgkin-Katz current equation, with extracellular calcium ([Ca $\left.]_{0}\right)$ equal to $25 \mathrm{~mm}$ and 


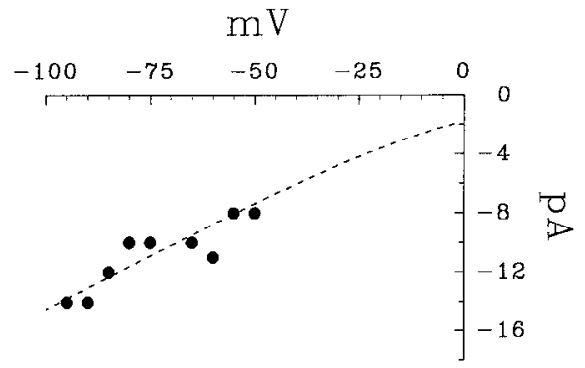

Figure 2. Difference $I-V$ curve in high-Ca ${ }^{2+}$ saline. A series of $300 \mathrm{msec}$ pulses to voltages between -95 and $-50 \mathrm{mV}$ was applied from a holding voltage of $-60 \mathrm{mV}$ before and $15 \mathrm{~min}$ after applying $1 \mathrm{~mm}$ 8-bromocGMP. The experiment was carried out in $\mathrm{Na}^{+}$-free, high-Ca ${ }^{2+}$ saline containing $10 \mathrm{mM}$ TEA and $1 \mu \mathrm{M}$ TTX. Data points were obtained by subtracting the stcady-statc current mcasurcd during cach stcp in normal saline from the current during the corresponding step in cGMP. The dashed line shows the expected $I-V$ curve for a $\mathrm{Ca}^{2+}$ current calculated from the Goldman-Hodgkin-Katz current equation assuming $[\mathrm{Ca}]_{\mathrm{i}}=70$ $\mathrm{nM}$ and $[\mathrm{Ca}]_{\mathrm{o}}=25 \mathrm{~mm}$.

$[\mathrm{Ca}]_{\mathrm{i}}$ equal to $70 \mathrm{~nm}$. This provides a reasonable approximation to the data and suggests a reversal potential more positive than +40 $\mathrm{mV}$. Because the $I-V$ curve was measured in $\mathrm{Na}^{+}$-free external saline, $\mathrm{Na}^{+}$is excluded as the carrier of inward current. Contamination from potassium currents is minimal because the pipette solution contained $156 \mathrm{mM} \mathrm{Cs}^{+}$in place of $\mathrm{K}^{+}$, and the external saline contained $10 \mathrm{~mm}$ TEA to suppress currents flowing in potassium channels. In addition, the calculated equilibrium potential for $\mathrm{Cl}^{-}$is $-60 \mathrm{mV}$, equivalent to the holding potential. Under these conditions, $\mathrm{Ca}^{2+}$ is the most likely candidate to carry the cyclic nucleotide-dependent inward current. For these reasons, and because the current is blocked by $\mathrm{Mn}^{2+}$ and $\mathrm{Ba}^{2+}$, we conclude that $\mathrm{Ca}^{2+}$ carries a significant fraction of the current activated by 8-bromo-cGMP, even in normal saline.

The amplitudes of cyclic nucleotide-dependent inward currents measured in normal saline (average current density $=0.40 \pm 0.12$ $\mathrm{pA} / \mathrm{pF}$, mcan $\pm \mathrm{SEM} ; n=8)$ and high-Ca ${ }^{2+}$ saline $(0.27 \pm 0.18$ $\mathrm{pA} / \mathrm{pF} ; n=3$ ) were not statistically different ( $p=0.6$, two-tailed $t$ test). This does not match the simple expectation for a $\mathrm{Ca}^{2+}$ selective current because one would expect the current density at a particular voltage to increase as the external $\mathrm{Ca}^{2+}$ concentration is raised. One possible explanation is that the current may saturate at $\mathrm{Ca}^{2+}$ concentrations above the physiological level in a manner similar to what is seen with voltage-dependent $\mathrm{Ca}^{2+}$ channels (Almers and McCleskey, 1984; Hess and Tsien, 1984). Alternatively, the pathway may be permeable to both $\mathrm{Na}^{+}$and $\mathrm{Ca}^{2+}$ with a conductance that depends on the ratio of permeant ion concentrations (Hagiwara, 1983; Hess and Tsien, 1984). The present data are not sufficient to decide between these alternatives.

\section{8-Bromo-cGMP increases $\mathbf{C a}^{2+}$ influx}

Fura-2 fluorescence imaging was used to measure changes in intracellular $\mathrm{Ca}^{2+}$ concentration during the application of 8-bromo-cGMP. Figure $3 A$ shows an example from a single cell bathed in normal saline; the result is representative of 20 experiments. Calcium concentration was measured ratiometrically at successive time points before and after adding $1 \mathrm{~mm}$ 8-bromocGMP to the bath. The figure shows that $[\mathrm{Ca}]_{i}$ increased from a resting value of $\sim 40 \mathrm{nM}$ to $\sim 120 \mathrm{~nm}$ within $15 \mathrm{~min}$. The time course of this increase is approximately the same as the time course of inward current activation measured with nystatin-patch
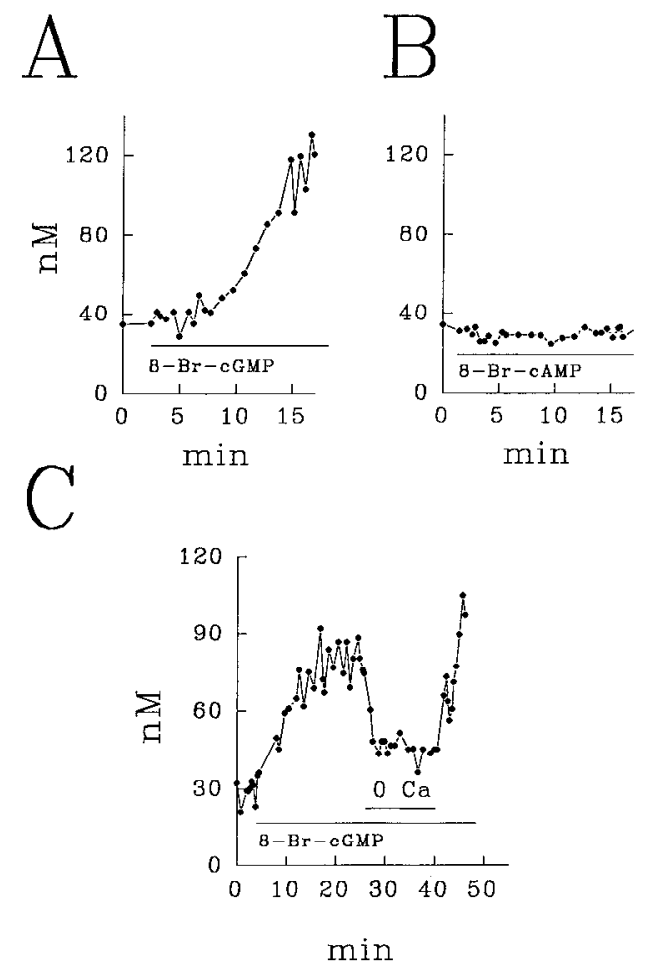

Figure 3. Fura-2 indaging shows that 8-bromo-cGMP elevates $[\mathrm{Ca}]_{i} \cdot A$, Measurement of $[\mathrm{Ca}]_{i}$ in a single cell loaded with Fura-2/AM and bathed in normal saline containing $1.8 \mathrm{mM} \mathrm{Ca}^{2+}$. At the time marked by the bar, $1 \mathrm{mM} 8$-bromo-cGMP was added to the bath. Each point represents a ratiomeiric determination of $[\mathrm{Ca}]_{i}, B$, The same experiment was repeated with $1 \mathrm{~mm}$ 8-bromo-cAMP, and the result shows that cAMP does not elevate $[\mathrm{Ca}]_{i}$ (representative of 10 experiments). $C$, The elevation in $[\mathrm{Ca}]_{i}$ during exposure to 8 -bromo-cGMP is attributable to $\mathrm{Ca}^{2+}$ influx. Ratiometric imaging applied to a cell bathed in normal saline; $1 \mathrm{~mm} 8$-bromocGMP was applied at the time marked by the bar. Twenty-five minutes later, the chamber volume was replaced with saline containing $70 \mathrm{~nm}$ free $\mathrm{Ca}^{2+}$ plus $1 \mathrm{~mm} 8$ bromo-cGMP for $15 \mathrm{~min}$. $\Lambda \mathrm{t}$ the end of this time, normal saline containing $1.8 \mathrm{mM} \mathrm{Ca}^{2+}$ plus $1 \mathrm{~mm}$ 8-bromo-cGMP was returned.

voltage clamp, which supports the conclusion that the inward current activated by 8-bromo-cGMP is carried in part by $\mathrm{Ca}^{2+}$. This effect was specific for cGMP because bath application of 1 mм 8-bromo-cAMP under the same conditions did not change $[\mathrm{Ca}]_{i}$ in any of the 10 experiments (Fig. $3 B$ ).

The increase in intracellular $\mathrm{Ca}^{2+}$ concentration results from increased $\mathrm{Ca}^{2+}$ influx. In the example in Figure $3 C$, the cell was exposed first to normal saline containing $1 \mathrm{~mm}$ 8-bromo-cGMP. After $20 \mathrm{~min}$, the external saline was exchanged for one containing the same concentration of cyclic nucleotide but a much lower $\mathrm{Ca}^{2+}$ concentration $\left(1.8 \mathrm{~mm} \mathrm{Ca}^{2+}\right.$ plus $4 \mathrm{~mm}$ EGTA; $70 \mathrm{~nm}$ free $\left.\mathrm{Ca}^{2+}\right)$, which resulted in a decrease in $[\mathrm{Ca}]_{\mathrm{i}}$ toward the resting level. This was reversed when normal saline was reintroduced. This result is representative of experiments on 20 cells and shows that the $[\mathrm{Ca}]_{\mathrm{i}}$ increase caused by 8 -bromo-cGMP is the result of $\mathrm{Ca}^{2+}$ influx from the extracellular compartment rather than $\mathrm{Ca}^{2+}$ release from intracellular stores.

The NO generator sodium nitroprusside (SNP) stimulates cGMP production in N1E-115 cells (McKinney et al., 1990; Thompson et al., 1995). We found that $100 \mu \mathrm{M}$ SNP, dissolved in normal saline, also causes the intracellular $\mathrm{Ca}^{2+}$ concentration to increase rapidly, reaching a value of $47 \pm 16$ nM (mean \pm SEM; 
A

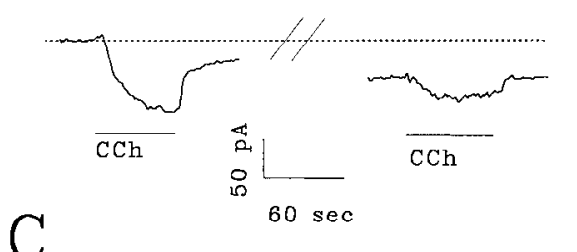

C

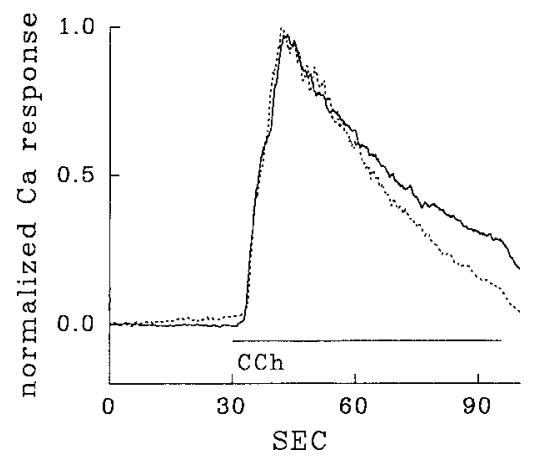

Figure 4. The inward currents activated by carbachol and 8-bromocGMP are not additive. $A$, Membrane current measured with nystatinpatch clamp (holding voltage $=-60 \mathrm{mV}$; normal saline). The initial holding current is shown by the dashed line; $1 \mathrm{~mm}$ carbachol $(C C h)$ was applied for $1 \mathrm{~min}$ at the time indicated by the bar. The inward current amplitude was $83 \mathrm{pA}$. $B$, The agonist was rinsed away, and $1 \mathrm{~mm} 8$-bromocGMP was added to the external saline. The cyclic nucleotide activated an inward current of $56 \mathrm{pA}$. After $15 \mathrm{~min}$, carbachol $(\mathrm{CCh})$ was applied a second time and caused an increment in inward current of $21 \mathrm{pA} . C$, Fura-2 imaging shows that incubation with 8-bromo-cGMP reduces the late phase of the $\mathrm{Ca}^{2+}$ response to carbachol $(\mathrm{CCh})$. Cells loaded with Fura-2/AM were stimulated twice with $1 \mathrm{~mm}$ carbachol (exposure to carbachol indicated by the bar). During the first stimulation, the cells were bathed in normal extcrnal salinc. The solid line shows the average $\mathrm{Ca}^{2+}$ response $(n=10)$. After rinsing, the saline was exchanged for one containing $1 \mathrm{~mm}$ 8-bromo-cGMP. After $15 \mathrm{~min}, 1 \mathrm{mM}$ carbachol was applied a second time. The $\mathrm{Ca}^{2+}$ response (dashed line) was corrected for the change in basal $[\mathrm{Ca}]_{i}$ level and normalized to the peak of the control response.

$n=9$ ) above the resting level within $90 \mathrm{sec}$. Incubation with 100 $\mu \mathrm{M}$ SNP for periods as long as $5 \mathrm{~min}$ had no effect on the peak amplitude of the $\mathrm{Ca}^{2+}$ response to carbachol. Because the peak $[\mathrm{Ca}]_{\mathrm{i}}$ change reflects intracellular $\mathrm{Ca}^{2+}$ release rather than $\mathrm{Ca}^{2+}$ influx (Mathes and Thompson, 1994), this finding shows that SNP does not alter the $\mathrm{Ca}^{2+}$ content of the $\mathrm{IP}_{3}$-releasable $\mathrm{Ca}^{2+}$ pool or the ability of agonist to stimulate $\mathrm{Ca}^{2+}$ release. These experiments provide further evidence that stimulation of the $\mathrm{NO} /$ guanylyl cyclase pathway is sufficient to activate $\mathrm{Ca}^{2+}$ influx.

\section{cGMP and muscarinic agonist activate the same inward current}

The inward current activated by 8-bromo-cGMP has several properties in common with the voltage-independent inward current activated by muscarinic agonist. In both cases the current is carried in part by $\mathrm{Ca}^{2+}$, and the currents reach approximately the same maximum current density. Both currents are susceptible to block by external $\mathrm{Mn}^{2+}$ and $\mathrm{Ba}^{2+}$, a property that is distinctly different from the other highly voltage-dependent $\mathrm{Ca}^{2+}$ channels expressed in these cells (Mathes and Thompson, 1994). These observations suggest that cGMP and muscarinic agonists might activate the same pathway. If this were so, we would expect that
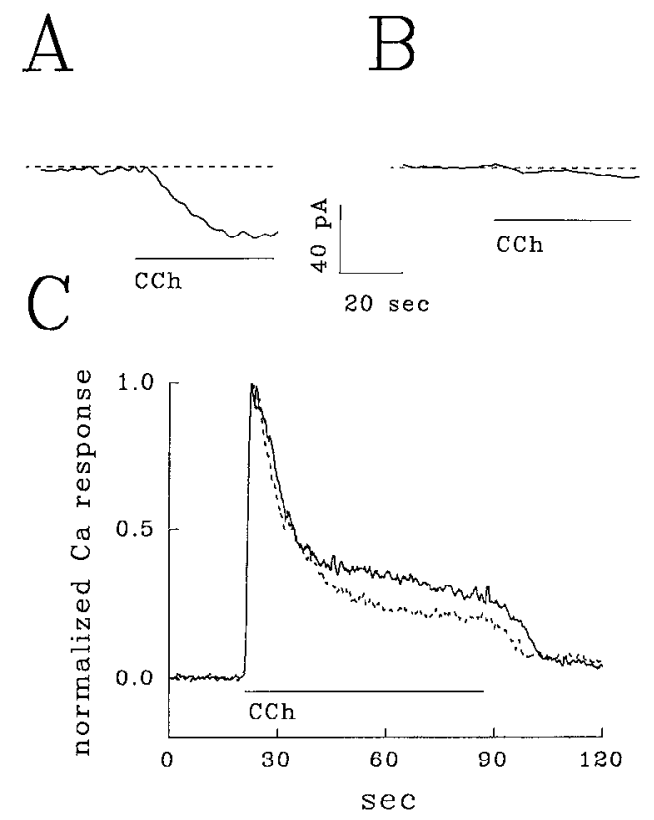

Figure 5. L-NMMA, a competitive inhibitor of NO-synthase, prevents activation of inward current by carbachol. $A$, Membrane current in a cell bathed in normal external saline during stimulation with $1 \mathrm{~mm}$ carbachol $(C C h$; agonist application indicated by the bar; holding voltage $=-60$ $\mathrm{mV}) . B$, The agonist was rinsed from the bath and replaced with saline containing $100 \mu \mathrm{m} \mathrm{L}$-NMMA. After $15 \mathrm{~min}, 1 \mathrm{~mm}$ carbachol dissolved in saline plus $100 \mu \mathrm{M}$ L-NMMA was applied a second time. $C$, Fura-2 imaging shows that L-NMMA reduces the plateau in the $\mathrm{Ca}^{2+}$ response to carbachol. Cells loaded with Fura- 2 and bathed in normal saline were stimulated with $1 \mathrm{mM}$ carbachol for the period indicated. The average response is shown by the solid line $(n=10)$. The agonist was rinsed from the chamber with saline containing $100 \mu \mathrm{M}$ L-NMMA. After $15 \mathrm{~min}$, the cells were stimulated a second time with $1 \mathrm{~mm}$ carbachol (dissolved in saline plus L-NMMA), and the responses were averaged (dashed line). The responses were normalized to the same peak amplitude.

cGMP would compete with carbachol for activation of the current and thereby reduce the increment in current amplitude that occurs when carbachol is applied. Figure 4 shows the results of a voltage-clamp experiment designed to test this prediction. In $A$, the current in response to $1 \mathrm{~mm}$ carbachol reached a steady amplitude of $83 \mathrm{pA}$. The agonist was washed away, and the cell was incubated in saline containing $1 \mathrm{~mm}$ 8-bromo-cGMP. This resulted in an inward current that reached $56 \mathrm{pA}$ after $15 \mathrm{~min}$. Carbachol was applied a second time in the presence of 8-bromocGMP, and now the agonist activated an inward current of $21 \mathrm{pA}$, $25 \%$ of the control current amplitude. The decrease in the carbachol response is in approximate proportion to the inward current activated by 8-bromo-cGMP. In three experiments, the average decrease in the carbachol response after $15 \mathrm{~min}$ in $1 \mathrm{mM}$ 8-bromo-cGMP was $91 \pm 11 \%$ (mean $\pm \mathrm{SD}$ ).

The observation that the inward currents activated by 8-bromocGMP and by carbachol do not sum is consistent with the hypothesis that cGMP and agonist activate the same pathway. This was tested further in a Fura-2 imaging experiment. The $\mathrm{Ca}^{2+}$ response to $1 \mathrm{~mm}$ carbachol was recorded in the same group of 10 cells, first under control conditions and then after a 15 min incubation with $1 \mathrm{~mm}$ 8-bromo-cGMP. The cyclic nucleotide caused a 50-100 nM increase in $[\mathrm{Ca}]_{\mathrm{i}}$ in different cells. The average peak amplitude of the response to the second carbachol application was $8 \%$ smaller than the first response, which is approximately the decrease ex- 
Table 1. Effects of inhibitors of cGMP production on inward current

\begin{tabular}{|c|c|c|}
\hline & $\mathrm{pA}$ & $\mathrm{pA} / \mathrm{pF}$ \\
\hline Control & $\begin{array}{l}99 \pm 16 \\
(n=3)\end{array}$ & $0.34 \pm 0.04$ \\
\hline L-NMM $\Lambda$ & $\begin{array}{c}4 \pm 4 \\
(n=4)\end{array}$ & $0.02 \pm 0.02^{*}$ \\
\hline Control & $\begin{array}{l}86 \pm 34 \\
(\mathrm{n}=5)\end{array}$ & $0.28 \pm 0.14$ \\
\hline D-NMMA & $\begin{array}{l}88 \pm 35(\mathrm{NS}) \\
(\mathrm{n}=6)\end{array}$ & $0.28 \pm 0.16(\mathrm{NS})$ \\
\hline Control & $\begin{array}{l}42 \pm 29 \\
(n=3)\end{array}$ & $0.13 \pm 0.05$ \\
\hline LY 83583 & $\begin{array}{c}0 \pm 0 \\
(n=3)\end{array}$ & $0 \pm 0^{*}$ \\
\hline Control & $\begin{array}{l}49 \pm 30 \\
(n=5)\end{array}$ & $0.21 \pm 0.10$ \\
\hline $10 \mu \mathrm{M}$ Rp-8-pCPT-cGMPs & $\begin{array}{l}14 \pm 9 \\
(n=4)\end{array}$ & $0.06 \pm 0.04^{*}$ \\
\hline
\end{tabular}

${ }^{*} p<0.01$ (matched pairs $t$-test applied to percentage change in current density). NS, not significant at the 0.05 level.

pected from muscarinic receptor desensitization under control conditions (Wang and Thompson, 1994; Mathes and Thompson, 1995). We showed previously that the peak increase in $[\mathrm{Ca}]_{i}$ is attributable to $\mathrm{Ca}^{2+}$ release from internal stores and that $\mathrm{Ca}^{2+}$ influx does not contribute to the signal until after the peak (Mathes and Thompson, 1994). The observation that the peak $[\mathrm{Ca}]_{i}$ increase does not change more than expected from desensitization makes two points. It shows that 8-bromo-cGMP does not inactivate the agonist receptor or the intermediate steps in the signaling cascade that lead to intracellular $\mathrm{Ca}^{2+}$ release. It also shows that the cyclic nucleotide does not by itself deplete intracellular stores of $\mathrm{Ca}^{2+}$. This is important because store depletion could cause the production of an independent factor, unrelated to cGMP, that could act as a second messenger to activate a refilling $\mathrm{Ca}^{2+}$ current (Putney and Bird, 1993). Figure $4 C$ shows the average calcium signal during the application of carbachol under control conditions (solid line) and after 8-bromo-cGMP (dashed line). The change in basal $[\mathrm{Ca}]_{\mathrm{i}}$ was subtracted and the responses were normalized to the same peak amplitude to emphasize the change in waveform. The $\mathrm{Ca}^{2+}$ signal decays more rapidly in cells treated with cGMP than in control cells. Calcium influx normally contributes to the $\mathrm{Ca}^{2+}$ signal at this late stage, prolonging the falling phase of the response (Mathes and Thompson, 1994). Because the response waveform does not change during repeated applications of agonist under control conditions, the increased rate of decay of $[\mathrm{Ca}]_{i}$ is a result of the exposure to cyclic nucleotide (Wang and Thompson, 1994). Our interpretation is that incubation with 8-bromo-c(iMP activates $\mathrm{Ca}^{2+}$ influx toward saturation and thereby reduces the further activation of $\mathrm{Ca}^{2+}$ influx by agonist. The decrease in the late phase of the $[\mathrm{Ca}]_{\mathrm{i}}$ response to agonist by previous exposure to 8-bromo-cGMP supports the hypothesis that cGMP and carbachol activate the same $\mathrm{Ca}^{2+}$ influx pathway.

\section{The activation of $\mathrm{Ca}^{2+}$ influx by muscarinic agonist is prevented by inhibitors of NO-synthase}

In this cell line, activation of M1 receptors by carbachol causes a rapid increase in cGMP. cGMP production is prevented when
A

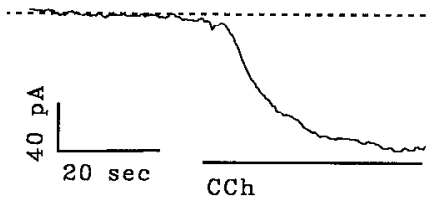

B

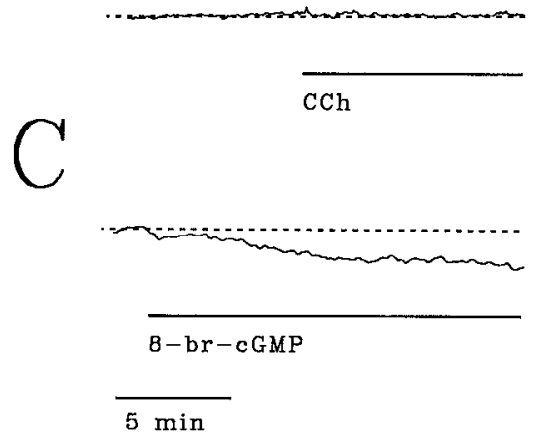

Figure 6. I -NMMA does not prevent the activation of inward current by 8-bromo-cGMP. A, Nystatin-patch recording of membrane current activated by $1 \mathrm{~mm}$ carbachol $(\mathrm{CCh}$ ) (agonist application indicated by bar; normal saline; $-60 \mathrm{mV}$ holding potential). $B$, The agonist was washed from the chamber, and saline containing $100 \mu \mathrm{M}$ L-NMMA was added. After $15 \mathrm{~min}, 1 \mathrm{~mm}$ carbachol $(C C h)$ was applied a second time and failed to elicil a response. $C$, The agonist was rinsed from the chamber, again with saline containing $100 \mu \mathrm{M}$ L-NMMA, and 15 min later saline containing $1 \mathrm{mM}$ 8-bromo-cGMP plus $100 \mu \mathrm{M}$ L-NMMA was added. The records were extracted from a continuous recording from the same neuron.

NO-synthase is blocked with the competitive inhibitor L-NMMA (McKinney et al., 1990; Thompson et al., 1995), and in the present experiments we found that L-NMMA also prevents the activation of $\mathrm{Ca}^{2+}$ influx by carbachol. An example is shown in Figure 5 . Application of $1 \mathrm{~mm}$ carbachol under control conditions activated an inward current that reached an amplitude of $43 \mathrm{pA}$ (Fig. 5A). The cell was incubated in saline containing $100 \mu \mathrm{M}$ L-NMMA for 15 min before carbachol was applied a second time. On the second application, the agonist elicitcd an inward current of $5 \mathrm{pA}$, equal to $11 \%$ of the control value (Fig. $5 B$ ). In four experiments with $100 \mu \mathrm{M}$ L-NMMA, the inhibitor reduced the inward current by 96 $\pm 9 \%$ (mean $\pm \mathrm{SD}$ ) (Table 1). Identical treatment with the inactive isomer D-NMMA had no effect on the activation of inward current by carbachol (Table 1). 8-Bromo-cGMP is able to activate inward current in the presence of L-NMMA. In the example illustrated in Figure 6, carbachol activated an inward current of $106 \mathrm{pA}$ under control conditions $(A)$. After a $15 \mathrm{~min}$ incubation with $100 \mu \mathrm{M}$ L-NMMA, a second application of carbachol failed to activate inward current, indicating that the pathway was completely blocked $(B)$. The agonist was rinsed from the chamber, and $1 \mathrm{~mm}$ 8-bromo-cGMP was added in the continued presence of L-NMMA. This resulted in a gradual increase in inward current that reached $35 \mathrm{pA}$ after $15 \mathrm{~min}\left(C^{\prime}\right)$, indicating that the cyclic nucleotide can bypass the NO pathway to activate the current directly.

Fura-2 imaging experiments showed that inhibition of NOsynthase with L-NMMA reduces $\mathrm{Ca}^{2+}$ influx in response to muscarinic agonist. Figure $5 C$ shows the average change in $[\mathrm{Ca}]_{\mathrm{i}}$ in 10 

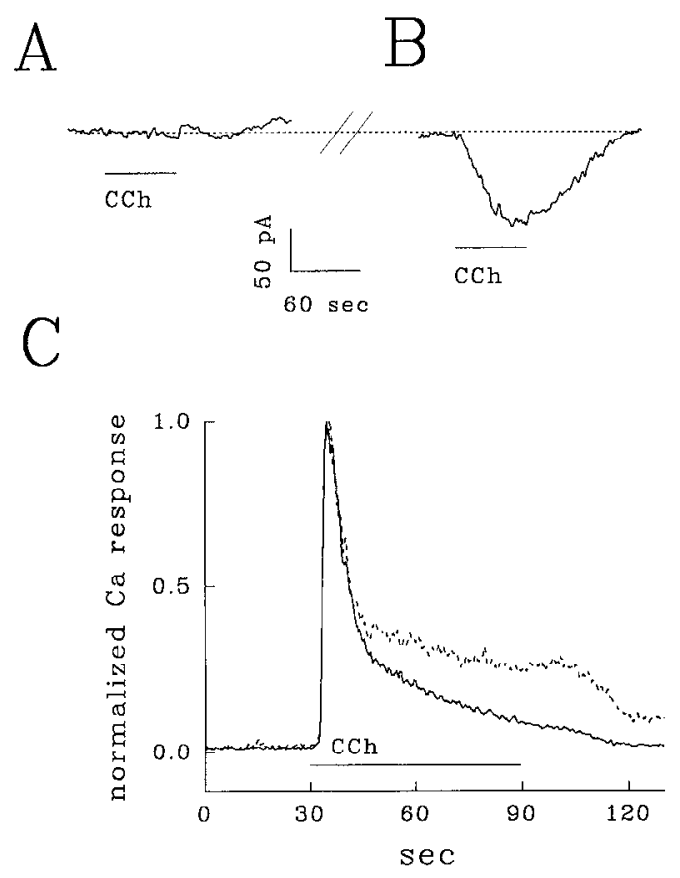

Figure 7. The reversible guanylyl cyclase inhibitor LY83583 blocks acti vation of inward current by carbachol. $A$, Membrane current in a cell incubated with $10 \mu \mathrm{M}$ LY83583 for $15 \mathrm{~min}$ and voltage-clamped to -60 $\mathrm{mV} ; 1 \mathrm{~mm}$ carbachol $(C C h)$ dissolved in saline plus $10 \mu \mathrm{M} L Y 83583$ was applied at the time indicated by the $b a r$. $B$, The agonist and LY 83583 were washed from the chamber with normal saline, and after $15 \min 1 \mathrm{~mm}$ carbachol $\left(C^{\prime}(h)\right.$ was applied a second time. $C$, Fura-2 imaging shows that LY83583 reduces the plateau in the $\mathrm{Ca}^{2+}$ response to carbachol $(\mathrm{CCh})$. Cells loaded with Fura-2 were incubated with saline containing $10 \mu \mathrm{M}$ LY83583 for $15 \mathrm{~min}$ before stimulating with $1 \mathrm{~mm}$ carbachol dissolved in the same saline. The average $\mathrm{Ca}^{2+}$ response is shown by the solid line ( $n$ $=10$; carbachol stimulation indicated hy the har). The inhibitor was rinsed from the chamber with normal saline. After $15 \mathrm{~min}, 1 \mathrm{~mm}$ carbachol was applied a second time, and the average response in the same 10 cells is shown by the dashed line (normalized by peak amplitude).

cells during carbachol stimulation under control conditions (solid line). The falling phase of the $\mathrm{Ca}^{2+}$ signal is characterized by a plateau that results from $\mathrm{Ca}^{2+}$ influx (Mathes and Thompson, 1994). After the agonist was washed away, the cells were incubated with $100 \mu \mathrm{M}$ I-NMMA for $15 \mathrm{~min}$ before carbachol was applied a second time (dashed line; normalized to the peak of the control response). This had no effect on the basal level of $[\mathrm{Ca}]_{i}$. The peak amplitude of the $\mathrm{Ca}^{2+}$ response during the second agonist application was reduced by $11 \%$, a decrease within the range expected from muscarinic receptor desensitization. L-NMMA caused a greater decrease in the plateau, which is consistent with inhibition of $\mathrm{Ca}^{2+}$ influx. D-NMMA had no effect on the $\mathrm{Ca}^{2+}$ response to carbachol. We conclude that the NOsynthase inhibitor prevents the activation of $\mathrm{Ca}^{2+}$ influx by agonist, but $\mathrm{L}-\mathrm{NMMA}$ does not cause $\mathrm{Ca}^{2+}$ release by itself and does not affect $\mathrm{Ca}^{2+}$ release by agonist.

\section{Inhibition of guanylyl cyclase blocks activation of $\mathrm{Ca}^{2+}$ current by agonist}

The guanylyl cyclase inhibitor LY83583 (Mulsch et al., 1988) blocks the activation of inward current by carbachol. In the example shown in Figure $7 A$, the cell was incubated in saline containing $10 \mu \mathrm{M}$ LY83583 for $15 \mathrm{~min}$ before a saturating concentration of carbachol ( $1 \mathrm{mM}$ ) was applied in the continued presence of inhibitor. There was no effect of agonist on mem-

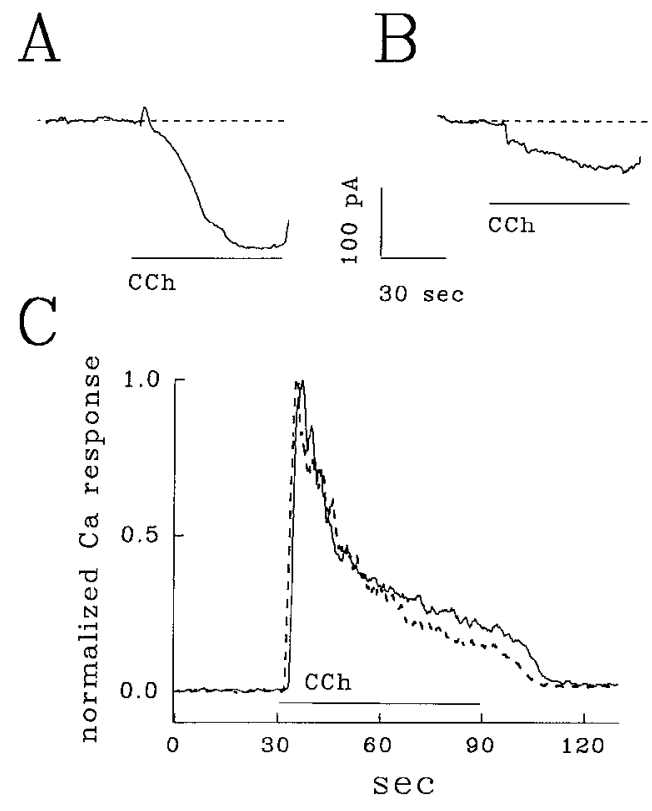

Figure 8. Rp-8-pCPT-cGMPS, an inhibitory analog of cGMP, reduces the activation of inward current by carbachol. $A$, Membrane current recorded with nystatin-patch clamp during the application of $1 \mathrm{~mm}$ carbachol $(\mathrm{CC}$; time shown by the bar) to a cell bathed in normal saline (holding voltage $=-60 \mathrm{mV}$ ). $B$, Membrane current during a second agonist application after $15 \mathrm{~min}$ incubation in saline containing $10 \mu \mathrm{M}$ Rp-8-pCPT-cGMPS. $C$, Fura-2 imaging shows that Rp-8-pCPT-cGMPS reduces the plateau in the $\mathrm{Ca}^{2+}$ response to agonist. The response to $1 \mathrm{~mm}$ carbachol $(\mathrm{CCh})$ in a single cell bathed in normal saline is shown by the solid line. The agonist was rinsed away, and saline with $100 \mu \mathrm{M} \mathrm{Rp}-8-$ pCPT-cGMPS was added. After $15 \mathrm{~min}$, the agonist was applied a second time in the presence of inhibitor (dashed line; normalized by peak amplitude).

brane current under these conditions. The chamber was rinsed with normal saline, and 15 min later the agonist was applied a second time. Carbachol now activated an inward current that reached $100 \mathrm{pA}$ (Fig. $7 B$ ). In three cells tested in this way, LY83583 completely and reversibly blocked the activation of inward current by agonist (Table 1). By using Fura-2 imaging, we found that LY83583 reduces the plateau in the $\mathrm{Ca}^{2+}$ response, which is the expected result if $\mathrm{Ca}^{2+}$ influx is blocked. Figure $7 C$ shows the increase in $[\mathrm{Ca}]_{\mathrm{i}}$ during stimulation with 1 mM carbachol measured after a 15 min incubation with $10 \mu \mathrm{M}$ LY83583 (solid line) and again 15 min after washing the inhibitor from the chamber (dashed line; normalized by peak amplitude). The inhibitor had no effect on basal $\mathrm{Ca}^{2+}$ concentration or on the peak amplitude of the $\mathrm{Ca}^{2+}$ response, but it strongly reduced the plateau. This provides pharmacological evidence that the activation of inward current by muscarinic agonist requires guanylyl cyclase activity.

\section{Rp-8-pCPT-cGMPS prevents activation of $\mathrm{Ca}^{2+}$ influx by agonist}

The membrane-permeable cGMP analog Rp-8-pCPT-cGMPS competes with cGMP for binding sites on cGMP-dependent protein kinase and acts as a competitive inhibitor of that enzyme (Butt et al., 1994). It may act in a similar way at cGMP binding sites associated with ion channels (Kramer and Tibbs, in press), although it apparently does not affect cGMP-regulated phosphodiesterases (Butt et al., 1994). In the example shown in Figure $8 A$, the inward current in response to $1 \mathrm{~mm}$ carbachol was re- 
corded first under control conditions and reached an amplitude of $167 \mathrm{pA}$. After $15 \mathrm{~min}$ in $10 \mu \mathrm{M}$ Rp-8-pCPT-cGMPS, carbachol was applied again, and the current reached $50 \mathrm{pA}, 30 \%$ of the control response (Fig. 8B). In five cells, $10 \mu \mathrm{M}$ Rp-8-pCPT-cGMPS reduced the inward current by $73 \pm 27 \%$ (mean \pm SD; Table 1$)$. Because the inhibitory cGMP analog competes with cGMP for binding sites on effector molecules, the strength of block is expected to increase with inhibitor concentration. In agreement with this prediction, we found that $15 \mathrm{~min}$ exposure to $100 \mu \mathrm{M} \mathrm{Rp}-8$ pCPT-cGMPS prevented the activation of inward current by agonist. These data support the view that cGMP binding is necessary for activation of the current. This is supported by Fura-2 imaging experiments. Figure $8 C$ shows the change in $[\mathrm{Ca}]_{\mathrm{i}}$ during the application of $1 \mathrm{~mm}$ carbachol under control conditions (solid line) and after a $15 \mathrm{~min}$ exposure to $100 \mu \mathrm{M}$ Rp-8-pCPT-cGMPS. The result is representative of 10 experiments. The inhibitor had no effect on the resting $\mathrm{Ca}^{2+}$ concentration or on the peak change in $[\mathrm{Ca}]_{i}$, which shows that it did not alter the $\mathrm{Ca}^{2+}$ content of internal stores or the ability of agonist to mobilize $\mathrm{Ca}^{2+} \cdot \mathrm{Rp}-8-$ pCPT-cGMPS did reduce the plateau phase of the response, which is consistent with decreased $\mathrm{Ca}^{2+}$ influx.

\section{DISCUSSION}

On the basis of these experiments, we conclude that cGMP is the necessary and sufficient link between muscarinic receptor activation and the activation of voltage-independent $\mathrm{Ca}^{2+}$ current. The same conclusion was reached for the activation $\mathrm{Ca}^{2+}$ influx in pancreatic acinar cells (Pandol and Schoeffield-Payne, 1990; Bahnson et al., 1993; Xu et al., 1994) and in an epithelial cell line (Bischof et al., 1995). Like the situation in acinar cells, the $\mathrm{Ca}^{2+}$ current in N1E-115 neuroblastoma cells is activated specifically by cGMP, and cAMP does not share this activity.

Evidence that 8-bromo-cGMP activates $\mathrm{Ca}^{2+}$ influx includes the following observations. The inward current is seen when cells are bathed in $\mathrm{Na}^{+}$-free saline when $\mathrm{Ca}^{2+}$ is present, and in this solution the extrapolated reversal potential is consistent with a $\mathrm{Ca}^{2+}$ current. The cyclic nucleotide also elevates $[\mathrm{Ca}]_{\mathbf{i}}$ in Fura-2 imaging experiments, and this develops over the same time course as the inward current measured with voltage clamp. The $[\mathrm{Ca}]_{i}$ increase results exclusively from $\mathrm{Ca}^{2+}$ influx rather than from $\mathrm{Ca}^{2+}$ release from internal stores. The inward current activated by 8-bromo-cGMP is blocked by external $\mathrm{Mn}^{2+}$ and $\mathrm{Ba}^{2+}$, and this unusual ionic sensitivity is shared with the inward current activated by muscarinic agonist (Mathes and Thompson, 1994). In addition, the currents activated by 8-bromo-cGMP and by muscarinic agonist are are not additive, indicating that agonist and 8-bromo-cGMP activate the same membrane current.

Muscarinic receptor activation causes a pronounced, 16-fold increase in cGMP within $30 \mathrm{sec}$ (Thompson et al., 1995). This is blocked by L-NMMA, a competitive inhibitor of NO-synthase, demonstrating that all of the guanylyl cyclase activity is attributable to the NO-sensitive form of the enzyme rather than to receptor-coupled cyclases (McKinney et al., 1990; $\mathrm{Hu}$ and $\mathrm{El}$ Fakahany, 1993; Thompson et al., 1995). The activation of inward current by agonist is also blocked by L-NMMA without affecting $\mathrm{IP}_{3}$ production (McKinney et al., 1990; Thompson et al., 1995). In addition, LY83583, a reversible inhibitor of guanylyl cyclase, and the cyclic nucleotide analog Rp-8-pCPT-cGMPS, a competitive inhibitor of cGMP-dependent protein kinase as well as cyclic nucleotide-gated channels (Butt et al., 1994; Kramer and Tibbs, in press), prevents the activation of inward current and $\mathrm{Ca}^{2+}$ influx

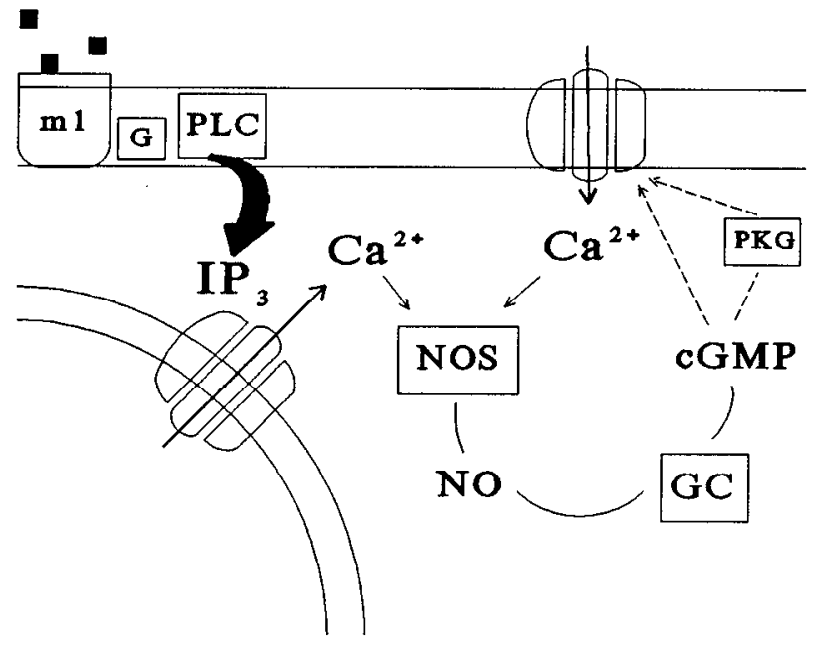

Figure 9. Model for the activation of $\mathrm{Ca}^{2+}$ current by muscarinic agonist. Binding of agonist to $\mathrm{M} 1$ receptors $(m l)$ activates phospholipase-C (PLC) via a G-protein $(G)$. The resulting increase in $I P_{3}$ concentration activates receptors associated with intracellular $\mathrm{Ca}^{2+}$ storage compartments to release $\mathrm{Ca}^{2+}$ into the cytosol. $\mathrm{Ca}^{2+}$ bound to calmodulin then activates NO-synthase (NOS), which catalyzes conversion of $\mathrm{L}$-arginine to $N O$ and citrulline. NO activates soluble guanylyl cyclase $(G C)$ to produce $c G M P$. cGMP activates $\mathrm{Ca}^{2+}$ influx cither by acting dircctly on cyclic nucleotidegated ion channels or via an additional intermediate, for example, cGMPdependent protein kinase ( $P K G$; dashed line).

by agonist. None of the inhibitors affect $\mathrm{Ca}^{2+}$ release from internal stores or the $\mathrm{Ca}^{2+}$ content of stores, which shows that inhibition of cGMP production uncouples $\mathrm{Ca}^{2+}$-store depletion from the activation of $\mathrm{Ca}^{2+}$ current.

Stimulation of NO-synthase requires $\mathrm{Ca}^{2+} /$ calmodulin, and cGMP production is prevented when the $\mathrm{Ca}^{2+}$ buffer bis(2aminophenoxy)ethane- $N, N, N^{\prime}, N^{\prime}$-tetra-acetic acid (or BAPTA) is introduced into the cell (Thompson et al., 1995). During the muscarinic response, $\mathrm{NO}$-synthase is driven in part by $\mathrm{Ca}^{2+}$ released from $\mathrm{IP}_{3}$-sensitive intracellular $\mathrm{Ca}^{2+}$ stores (Thompson et al., 1995), and therefore the cGMP signal has the potential to encode the depletion of $\mathrm{Ca}^{2+}$ stores. Maximum stimulation of cGMP production by carbachol, however, requires $\mathrm{Ca}^{2+}$ influx in addition to $\mathrm{Ca}^{2+}$ release. We found that cGMP production is reduced by $60 \%$ when $\mathrm{Ca}^{2+}$ influx is prevented under conditions in which $\mathrm{Ca}^{2+}$ release is not altered. This was interpreted as evidence that NO-synthase, or a necessary cofactor such as calmodulin, is localized to the vicinity of membrane $\mathrm{Ca}^{2+}$ channels (Thompson et al., 1995). Because cGMP formation is strongly dependent on $\mathrm{Ca}^{2+}$ influx and because $\mathrm{Ca}^{2+}$ influx is activated by cGMP, this pathway represents a positivefeedback loop that is critically poised to amplify the NO and cGMP signals. The feedback loop is diagrammed in Figure 9. This amplification process may explain the very rapid increase in cGMP concentration that occurs during the activation of muscarinic receptors.

The mechanism by which cGMP activates $\mathrm{Ca}^{2+}$ current in N1E-115 cells is not known, but there are two reasonablc possibilities. cGMP might directly activate a cyclic nucleotide-gated channel, or it might act indirectly, through a cGMP-dependent kinase or phosphatase for example, to modulate $\mathrm{Ca}^{2+}$ channels. Cyclic nucleotide-gated channels have been described in photoreceptors, olfactory neurons, and nonsensory neurons of vertebrates (Distler et al., 1994) and invertebrates (Huang and Gillette, 1993). Members of this family of heteromultimeric proteins share sequence homology in the cGMP-binding domain, but there is 
wide variability outside of this region, including variability in membrane-spanning segments thought to constitute the ion pore. This suggests that different members of the family may have different patterns of ionic selectivity or sensitivity to regulatory ligands. The inward currents activated by 8-bromo-cGMP and muscarinic agonist in N1E-115 neuroblastoma cells share several properties with cyclic nucleotide-gated channels, including the absence of voltage dependence, a conductance to $\mathrm{Ca}^{2+}$ that seems to saturate readily with increasing concentration (Hodgkin et al., 1985), possible $\mathrm{Ca}^{2+}$-dependent inactivation or self-block (Liu et al., 1994), and lack of permeability to $\mathrm{Ba}^{2+}$ and $\mathrm{Mn}^{2+}$ when $\mathrm{Ca}^{2+}$ is present (Capovilla et al., 1983). A definitive test for the presence of cyclic nucleotide-gated channels in N1E-115 cells will require additional experiments.

\section{REFERENCES}

Almers W, McCleskey EW (1984) Nonselective conductance in calcium channels of frog muscle: calcium selectivity in a single-file pore. J Physiol (Lond) 353:585-608.

Amano T, Richelson E, Nirenberg M (1972) Neurotransmitter synthesis by neuroblastoma clones. Proc Natl Acad Sci USA 69:258-263.

Bahnson TD, Pandol SJ, Dionne VE (1993) Cyclic GMP modulates depletion-activated $\mathrm{Ca}^{2+}$ entry in pancreatic acinar cells. $\mathbf{J}$ Biol Chem 268:10808-10812.

Bischof G, Brenan J, Bredt DS, Machen TE (1995) Possible regulation of capacitative $\mathrm{Ca}^{2+}$ entry into colonic epithelial cells by NO and cGMP. Cell Calcium 17:250-262.

Butt E, Eigenthaler M, Benieser HG (1994) Rp-8-pCPT-CGMPS, a novel cGMP-dependent protein kinase inhibitor. Eur J Pharmacol 269:265-268.

Capovilla M, Caretta A, Cervetto L, Torre V (1983) Ionic movements through light-sensitive channels of toad rods. J Physiol (Lond) 343:295-310.

Distler M, Bicl M, Flockrzi V, Hofmann F (1994) Expression of cyclic nucleotide-gated cation channels in non-sensory tissues and cells. Neuropharmacology 33:1275-1282.

Grynkiewicz G, Poenie M, Tsien RY (1985) A new generation of $\mathrm{Ca}^{2+}$ indicators with greatly improved fluorescence properties. J Biol Chem $260: 3440-3450$.

Hagiwara S (1983) Membrane potential-dependent ion channels in cell membrane: phylogenetic and developmental approaches. New York: Raven.

Hess P, Tsien RW (1984) Mechanism of ion permeation through calcium channels. Nature 309:453-456.

Hodgkin AL, McNaughton PA, Nunn BJ (1985) The ionic selectivity and calcium dependence of the light-sensitive pathway in toad rods. J Physiol (Lond) 358:447-468.

Horn R, Marty A (1988) Muscarinic activation of ionic currents measured by a new whole-cell recording method. J Gen Physiol 92:145-159.
Hu J, El-Fakahany E (1993) Role of intercellular and intracellular com-munication by nitric oxide in coupling of muscarinic receptors to activation of guanylate cyclase in neuronal cells. J Neurochem 61:578-585.

Huang R-C, Gillette R (1993) Co-regulation of cAMP-activated $\mathrm{Na}^{+}$ current by $\mathrm{Ca}^{2+}$ in neurones of the mollusk Pleurobranchaea. J Physiol (Lond) 462:307-320.

Kao JPY, Harootunian AT, Tsien RY (1989) Photochemically generated cytosolic calcium pulses and their detection by fluo-3. J Biol Chem 264:8179-8184.

Kimhi Y, Palfrey C, Spector I, Barak Y, Littauer UZ (1976) Maturation of neuroblastoma cells in the presence of dimethlysulfoxide. Proc Natl Acad Sci USA 73:462-466.

Kramer RH, Tibbs GR (1996) Antagonists of cyclic nucleotide-gated channels and molecular mapping of their site of action. $\mathbf{J}$ Neurosci, in press.

Liu M, Chen T-Y, Ahamed B, Li J, Yau K-W (1994) Calcium-calmodulin modulation of the olfactory cyclic nucleotide-gated cation channel. Science 266:1348-1354.

Mathes C, Thompson SH (1994) Calcium current activated by muscarinic receptors and thapsigargin in neuronal cells. J Gen Physiol 104:107-121.

Mathes C, Thompson SH (1995) The relationship between depletion of intracellular $\mathrm{Ca}^{2+}$ stores and activation of $\mathrm{Ca}^{2+}$ current in neuroblastoma cells. J Gen Physiol 106:975-994.

McKinney M, Bolden C, Smith C, Johnson A, Richelson E (1990) Selective blockade of receptor-mediated cyclic GMP formation in N1E-115 neuroblastoma cells by an inhibitor of nitric oxide synthesis. Eur $\mathrm{J}$ Pharmacol 178:139-140.

Mulsch A, Busse R, Liebau S, Forstermann U (1988) LY83583 interferes with the release of endothelium-derived relaxing factor and inhibits soluble guanylate cyclase. J Pharmacol Exp Ther 247:283-288

Pandol SJ, Schoeffield-Payne MS (1990) Cyclic GMP mediates the agonist stimulated increase in plasma membrane calcium entry in the pancreatic acinar cell. J Biol Chem 265:12844-12853.

Putney Jr JW, Bird GSJ (1993) The signal for capacitative calcium entry. Cell 75:199-201.

Thompson SH, Mathes C, Alousi AA (1995) Calcium requirement for cGMP production during muscarinic activation of N1E-115 cells. Am J Physiol 269:C979-C985

Wang SS-H. Thompson SH (1994) Measurement of changes in functional muscarinic acetylcholine receptor density in single neuroblastoma cells using calcium release kinetics. Cell Calcium 15:483-496.

Xu X, Star RA, Tortorici G, Muallem S (1994) Depletion of intracellular $\mathrm{Ca}^{2+}$ stores activates nitric-oxide synthase to generate cGMP and regulate $\mathrm{Ca}^{2+}$ influx. J Biol Chem 269:12645-12653.

Yoshii M, Tsunoo A, Narahashi T (1988) Gating and permeation of two types of calcium channels in neuroblastoma cells. Biophys $J$ $54: 885-895$. 